\title{
Socio-cultural factors of child domestic labour in the urban centre: A quantitative study of Peshawar, Pakistan
}

\author{
Jahanzeb Khan ${ }^{1} \mid$ Rahman Ullah*2-3 $^{2}$ Zafar Khan ${ }^{4}$
}

1. National Commission on the Rights of Child, Government of Pakistan, Islamabad, Pakistan.

2. Department of Governance, Politics, \& Public Policy, Abasyn University, Peshawar, Pakistan.

3. BBC News (World Service), British Broadcasting Corporation, Peshawar, Pakistan.

4. Department of Sociology, Faculty of Social Sciences, University of Peshawar, Peshawar, Pakistan.

*Correspondence Emails: rahmanjournalist@gmail.com | rahmanullah.khattak01@bbc.co.uk

\begin{abstract}
This research article investigates the socio-economic factors of child domestic labour. The quantitative methods utilize for the exploring the causal factors of child domestic labour. Data collected from 341 child domestic labour and their parents through snowball sampling techniques from the universe of the study. Univariate and Bi-variate statistics applied for the analysis of primary data. Poverty and over-population reinforce the child domestic labour in the urban centre of Pakistan. Large family size and unemployment compel parents to allow children in school age as a domestic worker. Gender discrimination and poverty also increase children's susceptibility to work as domestic labour. Pashtun, culturally more preferred children to keep them as a domestic labour and Pashtuns allow children to work inside home due to purdah (veil). Domestic child labour is also psychosextual and physical abused and it is not reported in majority cases. Socioeconomic protection of children and education significantly decrease the ratio of child domestic labour. It suggests to control over-population and provides socio-economic protection will decrease the ration of child domestic labour in the urban centre of Pakistan.
\end{abstract} Article History

Received:

March 2, 2021

Last Revised:

May 2, 2021

Accepted:

May 11, 2021

Published:

June 30, 2021

Keywords: financial inclusion, financial inclusion indicators, financial inclusion measurement, financial stability, banks financial stability, impact of financial stability.

How to Cite: Khan, J., Ullah, R., \& Khan, Z. (2021). Socio-cultural factors of child domestic labour in the urban centre: A quantitative study of Peshawar, Pakistan. Liberal Arts and Social Sciences International Journal (LASSIJ), 5(1), 525-536. https://doi.org/10.47264/idea.lassij/5.1.34

Publisher's Note: IDEA PUBLISHERS (IDEA Journals Group) stands neutral with regard to the jurisdictional claims in the published maps and the institutional affiliations.

Copyright: () 2021 The Author(s), published by IDEA PUBLISHERS (IDEA Journals Group). This is an Open Access article published under the Creative Commons Attribution-NonCommercial 4.0 International License (http://creativecommons.org/licenses/by-nc/4.0/) 


\section{Introduction}

Children work behind the closed door increases risk of exploitation, making them vulnerable to hazardous situations like sexual and physical abuses (Akhtar, 2005). Significant number of children have been working as child domestic labour in developing countries (Barrech et al., 2019). Street children are visible while children work as domestic labour are out of sight from communal eye and they face the worst forms of exploitation at the hands of their employers. The domestic workers face multiple issues where the employer unfortunately restrict children's movement and freedom. Child domestic labour (CDLs) is overburdened, and they work for long hours. The employer might not address their need for rest, food, and do not take care of their health (Blagbrough \& Glynn, 1999). Children associated with residential child domestic labour had no fixed timings and could extract work whether it is day or night especially in developing countries (Kamruzzaman \& Hakim, 2018). A significant number of children in Pakistan work as domestic labour and Khyber Pakhtunkhwa, the province of Pakistan, the poor people are compelled to allow their children as domestic labour (Haq et al., 2020).

Residential child labour has been increasing day by day generally in Pakistan and particularly in Khyber Pakhtunkhwa. This province has badly affected in the 'war on terror'. Purdah is rampant in Pashtun's society, which restricts women to come in front of males. Purdah and cultural symbols increase the ratio of the girl's child to domestic labour. Culturally, children as domestic labour is more acceptable in Pashtun society. Moreover, poverty, low-quality education, culture and lack of legislation marginalize children to work as domestic child labour generally in Pakistan and particularly in Khyber Pakhtunkhwa. Hence, the present study focuses on the socio-economic and cultural factors responsible for the domestic child labour. This study also explores the gender aspects of the child domestic labour. Objectives of the study are: a) To investigate the socio-economic factors compiling children on domestic child labour; b) To investigate the cultural factors, which compelled employers to keep children as domestic child, labour.

\section{Literature review}

Child domestic labour cannot be confined to any culture, community or society. It is universal observable fact (SPARC, 2012). The child domestic labour creates global threats to children at the global level. International Labour Organization estimated around 264,000 underage children being employed as CDLs in Pakistan (ILO, 2013). The actual data is still unknown and most of the children are working in the rural areas and faces hazardous situation like lengthy hours of work, undesirable working conditions and low salary (Bourdillon, 2009). The accurate data on CDL is not available in many countries of the world. Children work as domestic labour in majority cases is not accessible for the civil society and state institutions. CDLs are never found as a group and are difficult to be traced especially in houses. Domestic work does not belong to formal or informal labour market and is mostly unregistered, not explicitly stated in employment statistics. It is extremely hard to detect, explore and communicate with underage domestic workers in different parts of the world. In this regard, the International Programme on the Elimination of Child Labour (2004) report indicates some vital statistics of several nations. Approximately, two million children are working as a household labour in South Africa, 559,000 children in Brazil, 250,000 in Haiti, 2 million in Kenya. In Pakistan approximately, 264,000 children are working as a domestic labour especially in the urban centre. In the south Asians countries, the problem of domestic child labour is more visible as compared to the developed counties. In India, 20\% of all children 
under 14 working as a domestic labour. Moreover, in Africa $60 \%$ of all girls working between the ages of 10-14 are involved in household service (Hindman, 2009).

In South Asia and Africa, the parents of these underage children are less educated (Wyness, 2019). The illiterate parents do not know the importance of the legal contract for the employment which bound both the employers and employees by specifically highlighting terms and conditions. The legal contract bound the employers to submit deed document to the elder member of the family. However, several countries put domestic workers in a separate category and distinguish them from other workers in terms of their work and rest timings. Different countries define domestic workers, working hour differently especially in the underdeveloped countries of south Asia and Africa. In majority cases, the working hours for the domestic labour are not clearly defined and it create spaces for their exploitation (MillerMcLemore, 2019; Bales, 2000). In addition, it is lawfully acknowledged overtime to the routine working hours in different countries. The child labour is more visible in the developing and under developed countries. Street children are prominently visible in some countries, while child domestic workers are hidden from public eye, and they suffer the worst forms of exploitation at the hands of their employers. Employers have the legal immunity not to grant permission to individuals or agencies to enter and inspect their households. The domestic workers face multiple issues where the employer can unfortunately restrict children's movement, freedom (Blagbrough \& Glynn, 1999). The exploitation of the domestic child labour is rarely reporting in the world as well as in Pakistan.

The international community faces various challenges to protect the domestic workers in the different parts of the world. Children are kept under control and guidance of their employers, and they are more vulnerable to exploitation. The ILO's conventions and United Nations declare the domestic child labour as a serious threat to the violation of child rights. International organizations give emphasis on the legislation at the state level against the child domestic labour. However, many countries in the world have failed to introduce laws against the child domestic labour and they have failed to develop consensus over the legitimate age of work. Developing countries especially faces various socio-economic challenges to ban child domestic labour. Pakistan as a state might not in position to stop children access to employment even before they complete their basic schooling. Children who have not completed their required schooling should not be allowed to work as domestic labour (Edmonds \& Pavcnik, 2005; Rehman et al., 2019).

Pakistan is a signatory to international conventional regarding children rights and child domestic labour. Pakistan has passed several laws from the parliament and also made policies to fulfil the international obligation of the United Nation conventions. CDLs are deprived of all fundamental human rights given in the constitution of Pakistan (such as Articles 11, 25 (3), 25-A). The legal frameworks in many countries including Pakistan do not contain separate specific laws for prohibiting and regulating child domestic labour inside houses. The Constitution of Pakistan 1973 explicitly prohibits employing children of 14 years and below in factories, mines and other dangerous occupations. This provides a bar on children of younger and below age to enter domestic service as well. The government has failed to bring CDLs in the list of child labour laws since households are extremely difficult to be monitored. However, these laws are not effectively implemented, and child labour has not been stopped both in the rural and urban areas. Society has not been transformed in Pakistan and child labour is still acceptable in traditional cultural setting. The local culture resist to be monitored the household labour and it expose children who work as labour to exploitation (Ullah et al., 2018). 
They become exposed to fire, gases, petroleum, chemicals, liquids and also exposed to various diseases and infections. Aggression, sexual mistreatment, segregation, incarceration, unhealthy living, over-work and uncertainty are other well-known problems faced by domestic child labour in Pakistan. Child domestic labour faces intimidation, risks, mistreatment and violent behaviour behind the closed door. The government of Pakistan still does have concreate data about the child domestic labour. Negligence on the part of the government and society jeopardize the future of children. The government give responses only to those cases, which reported in the local media, and the children who work inside houses need strong and stable institutions to monitor the child domestic labour in Pakistan (Tarar et al., 2020).

\section{Theoretical model}

This research article focuses the socio-economic causal factors of domestic child domestic labour. The article focuses on the various aspects of domestic child labour; therefore, the eclectic approach is adopted, hence the two theories such as the ecological model and bargaining explore all the possible dimensions of the study in hand. The ecological model and bargaining theory elaborate the causal factors and as well as their exploitation at the society level. The ecological model give emphasis on the family environment (Eamon, 2001). Family environment pays pivotal role in shaping individuals. It is the prime responsibility of the family to give proper socialization to children and parents can protect them the physical and sexual abuses at the society level. Children expose to exploitation in community, neighbourhood, public places and in houses where they work as domestic labour. Community, which is sensitized about the child rights, can protect them from exploitation. Community awareness about the existing issues of child domestic labour cannot be ignore.

Societal stresses as poverty, low-income level, over population, inequality, social injustices, unemployment, and lack of education expose children to exploitation. Child protection needs holistic approach and different stockholders at the society level can protect them from exploration. The ecological model give emphasis on the role of family, community, society to protect them from exploitation. The family is considered the basic institution, which plays a pivotal role in personality development of the children. Community awareness about child domestic labour is essential for controlling domestic labour. This theory provides theoretical insight to this study. We cannot ignore the role of these all stakeholders in both their exploitation as well as in protection of children.

\section{Bargaining failures}

Bargaining failure associate the child labour with material needs and discuss its different aspects. The parents' failure to invest in an efficient level of human capital in their children increase the ration of domestic child labour (Brown et al., 2002; Baland \& Ziparo, 2018). The family head or parents try to engage all family member for the material gain and they fail to invest on the education of children. The work of children as a domestic labour provide support to parents and they provide economic support to their parents. The parents of domestic child labour are poor, and they expect immediate economic return from their children. The bargaining failure theory give emphasis on the parents bargaining position, which increase or decrease the ration of child domestic labour. This theory elaborates the different aspects of the child domestic labour and explain the finding of this study in the light of this theory. This theory also provides theoretical insight to this study. 


\section{Research methodology}

This study focuses the socio-economic causes of the child domestic labour. Keeping in view the nature of the study the positivism research philosophy in this research activity based on the demand of the topic, objectives and research questions of the study (Galliers, 1991). In the point of Rubin and Rubin (2012), "positivists assumed this that authenticity is permanent, directly quantifiable and understandable and that there is merely one fact, one outer realism. In opposition, physical researchers imagine that reality continually changes and can be understood only not directly, throughout the interpretations of citizens; they allow the prospect that there are various versions of realism. Citizens who are in trouble with such insecurity are more prone to decide the paradigm of quantification among its postulations of a sole, (countable) and predictable truth people, who can beard insecurity are more proven likely to support a qualitative model with its receiving of various perspectives of constantly changing reality and truth. Levin (1991) mentioned in his study that "Positivists consider that authenticity is constant and can be pragmatic and elaborated from practical goals and aim point of view, i.e., exclusive of interfere with the phenomena being studied. The followers of the positivism believe that there is only one type of fact of an event and there are not so many perceptions of that fact (Rubin \& Rubin, 2011).

The researcher used the quantitative research methods and collected the empirical data from the children and their parents because the children were not so mature to provide the in-depth information and most of their parents were not highly educated. The present study is quantitative, because it may be possible to collect basic information/data about the practice (age, sex, family background, level of education etc.) from house-to-house interviews. It is neither possible to collect in-depth qualitative data in this way from the children themselves. Much of today's quantitative data analysis is conducted through SPSS. The following lines explain the justification of universe and sample size.

\subsection{Universe of the study}

The present study is conducted in the urban areas of Hayatabad, Peshawar, Pakistan. Hayatabad is a satellite township of the Peshawar city. It has been named after the death of Hayat Muhammad Khan Sherpao, former Governor of Khyber Pakhtunkhwa and a notable leader of Pakistan People's Party. Hayatabad was developed as a residential area in Peshawar in the late 1970s. Hayatabad is in the south-western fringe of Peshawar city. The universe of the study included all the four phases of Hayatabad Satellite Township. Hayatabad is the more potential and attractive area for child domestic labour. The middle- or upper-class families often keep children as domestic labour.

\subsection{Sampling frame}

We can define a sampling as a part of population which is observed in order to make inferences about the total population. The selected four phases of Hayatabad comprise 11250 households. The sample size selected through the formula of Sekaran (Sekaran, \& Bougie, 2019). Therefore, contingency table as projected by Sekaran (2003) was used to sketch the sample size. As per the Sekaran (2003) proposal, a sample size of 341 was perfect for a population of 2812 of the sample areas. This model mostly applied in the business studies. Besides this, I applied the snowball for a sample of the gender-based categories. 


\section{Analysis and discussion}

The table-1 illustrates the connection of multiple dimensions of overpopulation with the child domestic labour. Over-population is counted as a social factor responsible for the child domestic labour. A highly significant association $(\mathrm{p}=0.000)$ calculated with early marriages. A highly significant association $(\mathrm{p}=0.000)$ observed with the large family size as higher source of income. Ultimately, child labour tends to increase in such families. Similar findings derived from the studies by Bales (2000) that over population and large family size are the reasons of child domestic labour. There was a strong and significant association $(\mathrm{p}=0.000)$ found with the higher number of sons which is a sign of prestigious status in society in Pashtun society. Furthermore, people in society who prefer to have a greater number of sons showed highly significant association ( $\mathrm{p}=0.000)$. According to (Ramirez-Machado, 2004) study whenever the family members are more in number and want to produce more children in search of a male child increase children's vulnerabilities to domestic child labour.

Table-1: Over population and child domestic labour

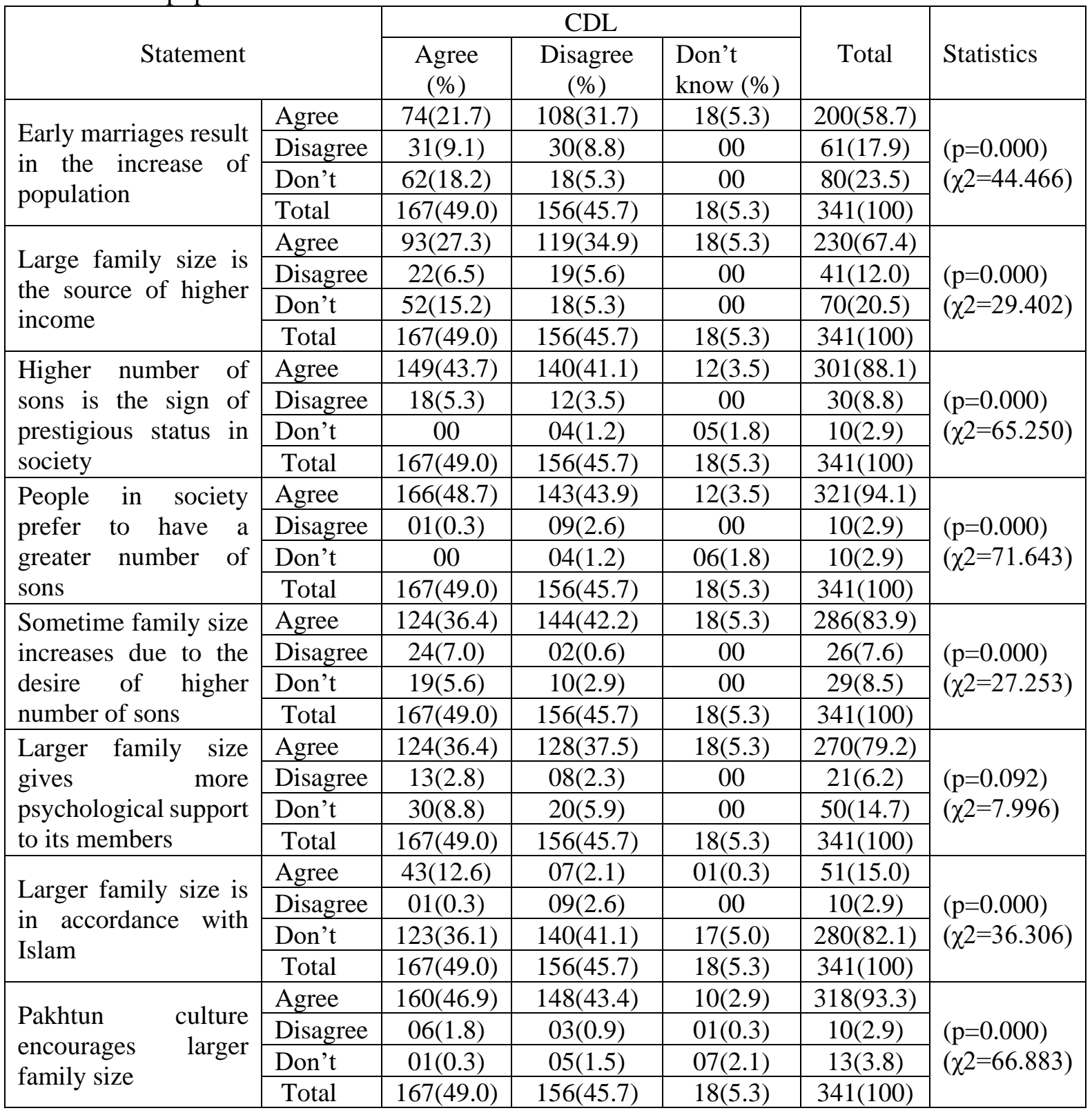


There is non-significant association $(\mathrm{p}=0.092)$ found with larger family size which gave more psychological support to its members. There is a highly significant association $(p=0.000)$ observed with larger family size which is in accordance with Islam. Similarly, a highly significant association $(\mathrm{p}=0.000)$ is found with the larger family size and early marriages as it is encouraged in Pashtun society. The findings of the study are similar to the findings of (Sanauddin, 2015; Abera et al., 2020). According to his study Islam and Pashtun culture are on one page they both like large family size and furthermore Pashtun belt like to produce more children in search of a male child. Therefore, these socio-cultural factors increase children's vulnerabilities, and they adopt domestic labour as profession for their survival. The ecological model also give emphasis on the role of family and community, and it shows that family failure to control over population increase the ratio of child domestic labour.

Table-2 highlights the association between various aspects of poor economic status and child domestic labour. There was a significant $(\mathrm{p}=0.031)$ observed with contract agreement by their parents with the employers. Similarly, a significant $(\mathrm{p}=0.019)$ relationship was observed with children working as CDLs because of poverty. Findings of the present study suggest that parents with low socio-economic status were badly affected the future of their children. Besides sending them to school, they send their children to work at other's homes. Hence, a large number of children remained uneducated, which deteriorated psychosocial makeup of their personalities. Similarly, a positive significant $(\mathrm{p}=0.002)$ relationship was found between parental unemployment and child domestic labour. The findings of present study are in connection with Horrell and Humphries (1995).

Economic factors are an important element of individuals as well as group life and well-being. Economic well-off sets over all being of society such as housing, education, health and psychological satisfaction. However, any form of break up in economic system of a society disrupts the proper function of society, which leads to social evil like poverty, domestic violence, and in turn, it led to child domestic labour (Bayissa, 2020). The study is in line with Alderman et al. (2006) and Daminger (2019) as the increased economic inequality and maximization of profit, status led to alienation of the poor class and they as well as their children were exposed to a number of risks in which child domestic labour was of prime importance. The above table highlighted the association between various aspects of poor economic status and child domestic labour. There was a significant $(\mathrm{p}=0.031)$ observed with contract agreement by their parents with the employers. Similarly, a significant $(p=0.019)$ relationship was observed with children working as a CDLs because of poverty. Findings of the present study suggested that parents with low socio-economic status badly affected the future of their children. Similarly, a positive significant $(p=0.002)$ relationship was found between parental unemployment and child domestic labour and Hindman (2009) revealed similar findings.

A significant $(\mathrm{p}=0.012)$ relationship was found with the satisfaction from working hours by children. A significant $(\mathrm{p}=0.019)$ relationship was observed where children economically support families. Furthermore, there was a significant association $(\mathrm{p}=0.001)$ observed with the CDLs satisfaction from the employer. There was a significant association $(p=0.019 \& 0.012)$ found with the government support and the NGO's support respectively in terms of education, economically and legally. The findings of the present study are in line with the study finds of Horrell and Humphries (1995). The bargaining failure theory also give emphasis on the socioeconomic protection of children and family (Fong, 2020). The study finding is in line with the bargaining failure theory and most of the poor children are more susceptible to exploitation. 
Table-2: Child domestic labour and poverty

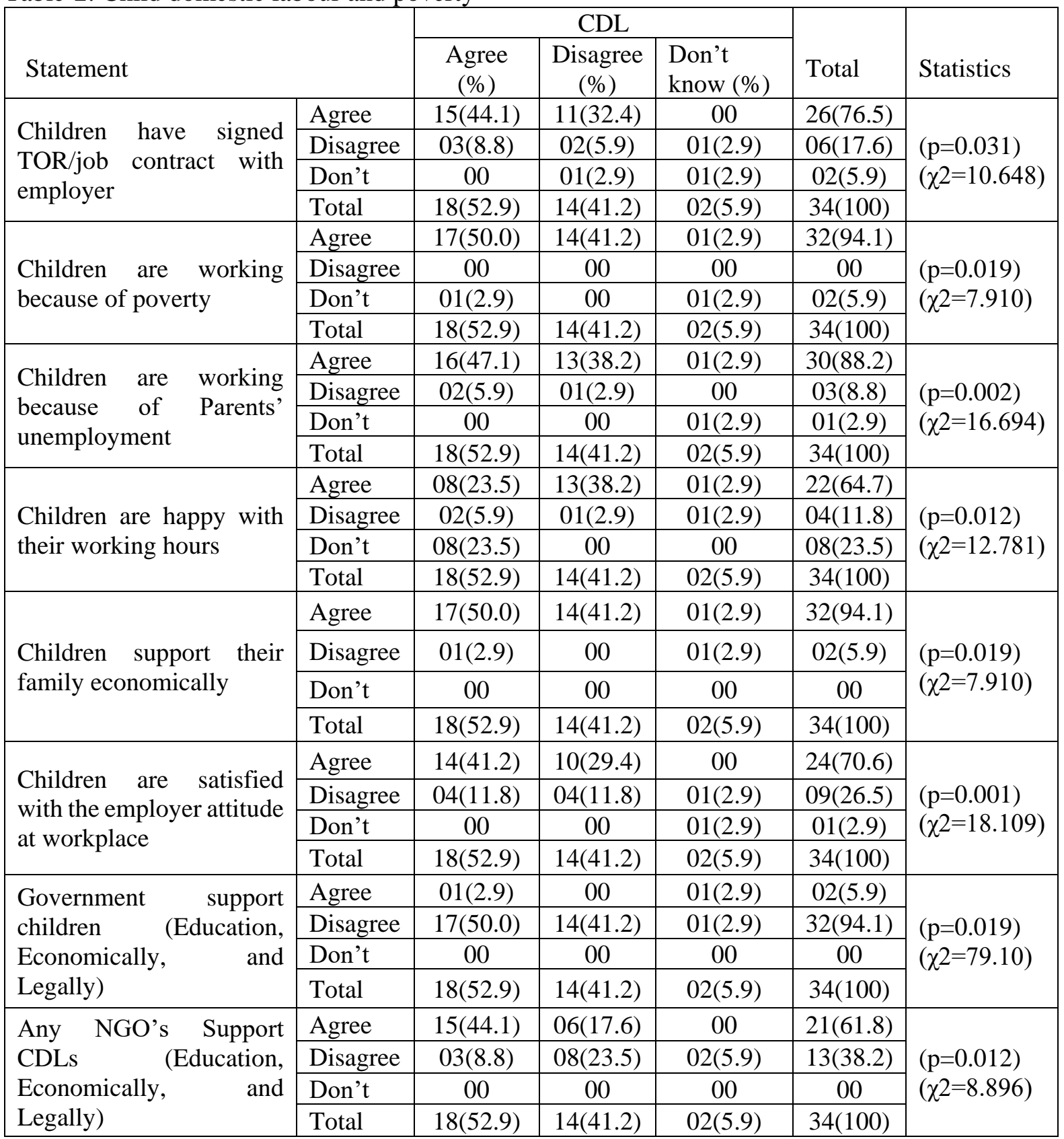

Source: Field data; 2018.

The table- 3 shows association between various aspects of poor economic status and child domestic labour. There is a highly significant association $(\mathrm{p}=0.000)$ found with CDL contract agreement with the employer. Similarly, a strongly significant association $(\mathrm{p}=0.000)$ observed with children working as a CDLs because of poverty. The facts were similar to the findings of Reynaert et al. (2009) who argued that poverty is the root cause behind child domestic labour. In the same manner, significant association $(\mathrm{p}=0.000)$ is found with the parental unemployment and child domestic labour. The result of this study supported by the findings of Avais et al., (2014). There was a significant association $(\mathrm{p}=0.002)$ found with the CDLs being happy and satisfied with their working hours. The results of this study are in line with the research study of Adams and Trost (2004), Şişli and Limoncelli (2019), according to their research study most of the children are not happy with their working hours because the owner of the working place 
does not provide the wages to the children according to their working hours. There is a significant association ( $\mathrm{p}=0.006$ ) found with the extra payment to the CDL for the overtime by the employer. Moreover, a glaringly significant association $(\mathrm{p}=0.000)$ observed in supporting the family economically by the child. There is a significant association $(p=0.019)$ found in relation to supporting CDL by the government and a highly significant association $(\mathrm{p}=0.000)$ observed with the supporting of CDL by the NGOs in terms of education, economically, and legally. The finding of the study is supported by the empirical work of Avais et al. (2014). According to them, it came to the surface that the government, NGOs and INGOs helped and supported the children to provide all the basic needs to them and tried their best to educate them properly along with other facilities.

Table-3: Child domestic labour and socio-economic protection

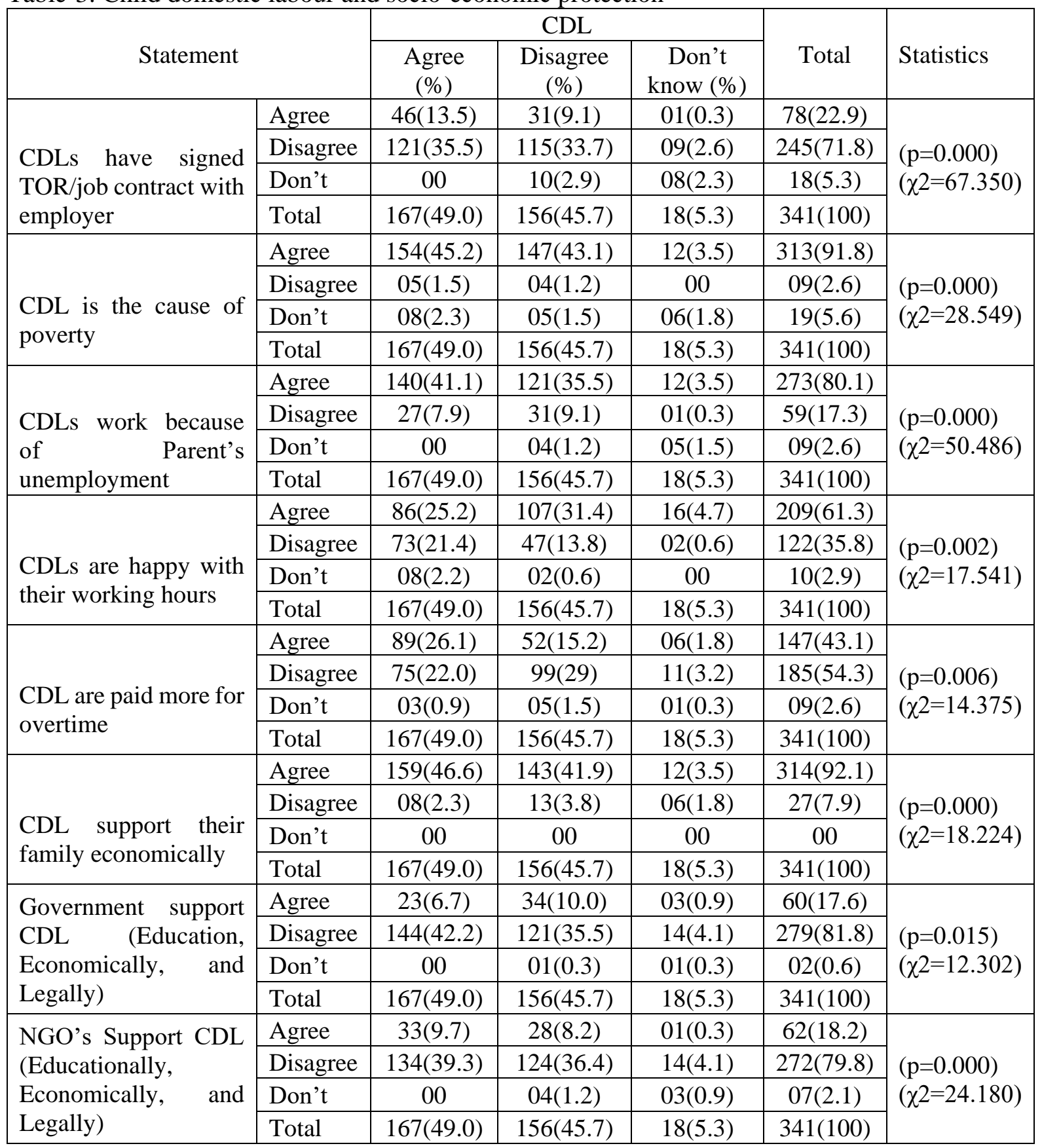




\section{Conclusion}

This study investigates the sociological aspects of child domestic labour in the urban centre of Pakistan. As mentioned above, the study is conducted in district Peshawar. In the light of study finding, it is revealed that over-population and large family size in Pashtun society and desire for male children increase the ratio of domestic child labour in Pashtun society. Poverty and unemployment of parents increase the susceptibility of children domestic work. Children of the broken family are compelled to work as domestic labour. Moreover, Pashtun culturally preferred to keep children for domestic labour because of the Purdah. Along with the social and economic factors of child domestic labour, the state failure to provide socio-economic protection push their citizen towards child labour. It is the prime responsibility of the state to protect children from all form of abuses and ensure food and health facilities to them. The socio-economic protection of domestic children will decrease the ratio of domestic children in Pashtun society. The primary data is endorsed the causal factors discuss in the ecological model and bargaining failure. The over-population and poverty are the two major factors, which expose children to exploitation and increase the ratio of child domestic labour.

\section{References}

Abera, M., Nega, A., Tefera, Y., \& Gelagay, A. A. (2020). Early marriage and women's empowerment: The case of child-brides in Amhara National Regional State, Ethiopia. BMC International Health and Human Rights, 20(1), 1-16. https://doi.org/10.1186/s12914-020-00249-5

Akhtar, N. (2005). The robustness of learning through overhearing. Developmental Science, 8(2), 199-209. https://doi.org/10.1111/j.1467-7687.2005.00406.x

Adams, B. N., \&Trost, J. (2004). Handbook of world families. Sage Publications.

Avais, M., Chandio, R., Shaikh, N., \&Mirza, A. (2014). Socio-economic causes of child labour in domestic work: A study of Sukkur city. International Journal of Science: Basic and Applied Research, 18(1), 410-416. http://dx.doi.org/10.2139/ssrn.2537340

Alderman, H., Hoogeveen, H., \& Rossi, M. (2006). Reducing child malnutrition in Tanzania: Combined effects of income growth and program interventions. Economics \& Human Biology, 4(1), 1-23. https://doi.org/10.1016/j.ehb.2005.07.001

Baland, J. M., \& Ziparo, R. (2018). Intra-household bargaining in poor countries. In towards gender equity in development (pp.69-96). https://library.oapen.org/bitstream/handle/20.500.12657/25125/9780198829591_To wards_Gender_Equity_in_Development.pdf?sequence=1\#page $=94$

Bales, K. (2000). Expendable people: Slavery in the age of globalization. Journal of International Affairs, 53(2), 461-484. http://www.jstor.org/stable/24357761

Bayissa, R. (2020). Attitude and Perception of Women on Domestic Violence Practiced by Husbands in Ethiopia. Liberal Arts and Social Sciences International Journal (LASSIJ), 4(1), 255-270. https://doi.org/10.47264/idea.lassij/4.1.22

Blagbrough, J., \& Glynn, E. (1999). Child domestic workers: Characteristics of the modern slave and approaches to ending such exploitation. Childhood,6(1), 51-56. https://doi.org/10.1177/0907568299006001004

Brown, D. K., Deardorff, A. V., \& Stern, R. M. (2002). The determinants of child labour: theory and evidence. School of Public Policy, University of Michigan.

Barrech, S., Din, M., \& Allauddin, A. (2019). Sociological analysis of domestic child labour. 
Pakistan Journal of Gender Studies, 19(1), $\quad$ 149-162. https://doi.org/10.46568/pjgs.v19i1.80

Bourdillon, M. (2009). Children as domestic employees: Problems and promises. Journal of children and poverty, 15(1), 1-18. https://doi.org/10.1080/10796120802677586

Daminger, A. (2019). The cognitive dimension of household labour. American Sociological Review, 84(4), 609-633. https://doi.org/10.1177/0003122419859007

Eamon, M. K. (2001). The effects of poverty on children's socioemotional development: An ecological systems analysis. Social work, 46(3), 256-266. https://doi.org/10.1093/sw/46.3.256

Edmonds, E. V., \& Pavcnik, N. (2005). Child labour in the global economy. Journal of Economic Perspectives, 19(1), 199-220. https://doi.org/10.1257/0895330053147895

Fong, K. (2020). Getting eyes in the home: child protective services investigations and state surveillance of family life. American Sociological Review, 85(4), 610-638. https://doi.org/10.1177/0003122420938460

Galliers, R. D. (1991). Strategic information systems planning: myths, reality and guidelines for successful implementation. European Journal of Information Systems, 1(1), 5564. https://doi.org/10.1057/ejis.1991.7

Haq, J. U., Khanum, S., \& Raza Cheema, A. (2020). The impact of trade liberalization on child labour in Pakistan. International Review of Applied Economics, 34(6), 769-784. https://doi.org/10.1080/02692171.2020.1782853

Hindman, H. D. (2009). The world of child labour: An historical and regional survey. ME Sharpe.

Horrell, S., \& Humphries, J. (1995). Women's labour force participation and the transition to the male-breadwinner family, 1790-1865. Economic History Review, 89-117. https://www.jstor.org/stable/2597872

ILO. (2013). Domestic workers across the world: Global and regional statistics and the extent of legal protection. International Labour Organization (ILO). http://www.ilo.org/travail/Whatsnew/WCMS_173363/lang--en/index.htm

Levin, M. (1991). The reification-realism-positivism controversy in macromarketing: A philosopher's view. Journal of Macromarketing, 11(1), 57-65. https://doi.org/10.1177/027614679101100106

Miller-McLemore, B. J. (2019). Let the children come: Reimagining childhood from a Christian perspective. Fortress Press.

Kamruzzaman, M., \& Hakim, M. A. (2018). A review on child labour criticism in Bangladesh: An analysis. International Journal of Sports Science and Physical Education, 3(1), 1-8. https://doi.org/10.11648/j.ijsspe.20180301.11

Rubin, H. J. \& Rubin, I. S. (2012). Qualitative interview: The art of hearing data ( $3^{\text {rd }} \mathrm{ed}$.). Los Angeles.

Ramirez-Machado, J. M. (2004). Domestic work, conditions of work and employment: A legal perspective. International Labour Office. http://adapt.it/adapt-indice-a-z/wpcontent/uploads/2014/09/ilo_domestic_work_2003.pdf

Rehman, A. U., Shah, M. I., Khan, K. \& Khan, I. U. (2019). Socio-Economic Impact of Bonded Child Labour in Pakistan. E-Journal of International and Comparative Labour Studies, 8(1), 54-64. http://ejcls.adapt.it/index.php/ejcls_adapt/article/view/644

Reynaert, D., Bouverne-de-Bie, M., \& Vandevelde, S. (2009). A review of children's rights literature since the adoption of the United Nations Convention on the Rights of the Child. Childhood, 16(4), 518-534. https://doi.org/10.1177/0907568209344270

Sekaran, U., \& Bougie, R. (2019). Research methods for business: A skill building approach. 
John Wiley.

Sanauddin, N. (2015). Proverbs and patriarchy: Analysis of linguistic sexism and gender relations among the Pashtuns of Pakistan. Doctoral dissertation, University of Glasgow.

Sisli, Z., \& Limoncelli, S. A. (2019). Child brides or child labour in a worst form? Journal of Labour and Society, 22(2), 313-324. https://doi.org/10.1111/lands.12407

Sekaran, U. (2003). Research methods for business. John Wiley \& Sons.

SPARC. (2012). The state of Pakistan's children. Society for the Protection of the Rights of the Child (SPARC), Islamabad.

Tarar, U. S., Naomi, S. S., \& Khan, M. A. (2020). Child Sexual Abuse in Pakistan: From Tears Shed to Lives Lost. Liberal Arts and Social Sciences International Journal (LASSIJ), 4(1), 35-43. https://doi.org/10.47264/idea.lassij/4.1.4

Ullah, S., Khan, I. U., \& Ali, T. (2018). Child Labour Migration and Access of their Parents' to Basic Needs: A Quantitative Study of Dir Upper, Pakistan. Liberal Arts and Social Sciences International Journal (LASSIJ), 2(1), 29-36. https://doi.org/10.47264/idea.lassij/2.1.4

Wyness, M. G. (2019). Childhood and society. Macmillan International Higher Education. 